\title{
SHORT-TERM FORECASTS OF THE DOMESTIC STEEL PRODUCTION VOLUME AND THE PROPORTION BETWEEN PRODUCTION IN THE INTEGRATED AND ELECTRIC PROCESS
}

\author{
Bożena GAJDZIK \\ Silesian University of Technology, Department of Material Engineering and Metallurgy, Faculty of Production \\ Engineering; bozena.gajdzik@polsl.pl
}

\begin{abstract}
Forecasting is an element of the decision-making process through which a desired vision of the future status of the company is worked out and determines the techniques of achieving it. Creating forecasts is a conscious action and it is based on a certain method. Statistical-econometric methods were used in this publication. The projections concerned steel production and the proportion between the applied technologies. The research covered the domestic steel industry. Due to the time span of the projections, which was assumed until 2020, the designated forecasts were acknowledged as short-term projections.
\end{abstract}

Keywords: forecast, steel production, integrated process, electric furnaces.

\section{Introduction}

Enterprises in a dynamic environment forecast changes concerning a lot of different areas of activity. When planning measures it is necessary to evaluate the set of problems and actions which offer an opportunity to reach the desired results. Forecasting is a part of the planning process. Forecasting means becoming involved in the future to undertake proactive measures. Looking ahead enables to answer the question: "What will happen?" and/or " What analyzed volumes will change?". Forecasting makes sense only if it covers a big set of empirical data respectively. In case of projecting or forecasting, extrapolation or interpolation is used based on numerous statistical-econometric methods. The choice of methods is left to the discretion of the researcher. For the purposes of this publication statistical methods were verified and those were chosen which were characterized by the smallest prognostic error.

The goal of this publication was to work out statistical short-term forecasts of the steel production volumes until 2020 broken down by steel production in accordance with the applied production technologies. The study was drawn up on the basis of statistical data. For creating the forecast, data on the total steel production volume, including basic converter and electrical steel from 2000 until 2015 were used. Ex-ante forecasts were made for the period 
from 2016 until 2020 - a five-year period. A crawling trend model - forecasting via the harmonic balance method was worked out for the studied phenomena in the domestic steel industry.

\section{A methodical procedure in projecting the steel production volume in total and according to the production processes}

In order to build a forecast of the steel production volume in total and according to a breakdown by respective technologies applied in the steel industry in Poland until 2020 (5 years), adaptive and econometric models (linear, non-linear and including autocorrelation) were used. Two paths of methodical procedure were assumed. The first methodical procedure was the following: Stage 1 Creating a forecast for the entire steel production. Stage 2a1. Creating a forecast for steel production through the converter process. Stage 2a2. Forecast assessment for steel production through the electric process. The second methodical procedure, in turn, covered: Stage 1. Creating a forecast for the entire steel production. Stage $2 \mathrm{~b} 1$. Creating a forecast for steel production through the electric process. Stage 2b2. Forecast assessment for steel production through the converter process. The adopted methodical procedure resulted from the fact that the steel obtained through the converter and electric processes made up the total steel production.

For the respective statistical methods used in the course of making projections the minimum value of one of the errors was adopted as the basis for the optimization of the point prediction value: the square root calculated from the mean squared error of the RMSE* simulated forecasts and the mean value of the relative error of the expired forecasts (Pawłowski, 1973, 1982; Sadowski, 1997). Among the tested prognostic methods optimum forecasts were chosen, taking into consideration the above-defined criteria for such exploration. The best method from among the set of optimum methods was chosen. It was the crawling trend method using the harmonic balance method. Table 1 contains a set of optimal methods used in the aforementioned research with respect to the steel production volume forecast. The methodical procedure, the verification of respective statistical methods were repeated with respect to steel production using the converter and electric processes. 
Table 1.

A set of optimal prognostic methods for the explored forecast areas ${ }^{1}$

\begin{tabular}{|c|c|c|c|c|c|}
\hline \multicolumn{6}{|c|}{ Projection of the total steel production } \\
\hline \multirow[t]{2}{*}{ No. } & \multirow[t]{2}{*}{ Method or forecast model } & \multicolumn{2}{|c|}{$\begin{array}{c}\text { Ex post } \\
\text { error }\end{array}$} & \multirow{2}{*}{$\begin{array}{c}\text { Ex ante } \\
\text { error } \\
\Psi\end{array}$} & \multirow{2}{*}{$\begin{array}{c}\text { Comments with respect } \\
\text { to the model } \\
\text { parameters }\end{array}$} \\
\hline & & $\Psi$ & $R M S E^{*}$ & & \\
\hline 1. & $\begin{array}{l}\text { The crawling trend method- forecasting via } \\
\text { the harmonic balance method }\end{array}$ & 0.044 & 0.521 & 0.0230 & $\begin{array}{l}\text { Number of elements in } \\
\text { the segment } \mathrm{k}=4\end{array}$ \\
\hline 2. & Autoregressive (AR) models $(1,2,4,5)$ & 0.061 & 0.692 & 0.0190 & AR Model $(1,2,4,5)$ \\
\hline 3. & Autoregressive (AR) models $(1,4,5)$ & 0.066 & 0.703 & 0.0065 & AR Model $(1,4,5)$ \\
\hline 4. & $\begin{array}{l}\text { Holt-Winters additive method (for different } \\
\text { actuation mechanisms) }\end{array}$ & 0.088 & 0.911 & 0.1092 & $\begin{array}{c}\text { Min. value: } \Psi \\
\alpha=0.0001 \\
\beta=0.2398 \\
\Phi=0.2597\end{array}$ \\
\hline 5. & $\begin{array}{l}\text { Holt-Winters additive method (for different } \\
\text { actuation mechanisms) }\end{array}$ & 0.088 & 0.911 & 0.1124 & $\begin{array}{c}\text { Min. value *RMSE } \\
\alpha=0.0001 \\
\beta=0.2395 \\
\Phi=0.2569\end{array}$ \\
\hline 6. & Line model (for illustrative purposes) & 0.089 & 0.924 & 0.0914 & $\begin{aligned} \mathrm{R} 2 & =0.1521 \\
\mathrm{p} & =0.1340\end{aligned}$ \\
\hline \multicolumn{6}{|c|}{ Converter steel production forecast } \\
\hline \multirow[t]{2}{*}{ No. } & \multirow[t]{2}{*}{ Method or forecast model } & \multicolumn{2}{|c|}{$\begin{array}{c}\text { Ex post } \\
\text { error }\end{array}$} & $\begin{array}{l}\text { Ex ante } \\
\text { error }\end{array}$ & \multirow{2}{*}{$\begin{array}{c}\text { Comments with respect } \\
\text { to the model } \\
\text { parameters }\end{array}$} \\
\hline & & $R M S E^{*}$ & $\Psi$ & $\Psi$ & \\
\hline 1. & $\begin{array}{l}\text { The crawling trend method- forecasting via } \\
\text { the harmonic balance method }\end{array}$ & 0.059 & 0.379 & 0.0046 & $\begin{array}{l}\text { Number of elements in } \\
\text { the segment } \mathrm{k}=4\end{array}$ \\
\hline 2. & Autoregressive (AR) models (1) & 0.124 & 0.772 & 0.0499 & AR Model (1) \\
\hline \multicolumn{6}{|c|}{ Forecasting steel production through the electric process } \\
\hline \multirow[t]{2}{*}{ No. } & \multirow[t]{2}{*}{ Method or forecast model } & \multicolumn{2}{|c|}{$\begin{array}{c}\text { Ex post } \\
\text { error }\end{array}$} & $\begin{array}{l}\text { Ex ante } \\
\text { error }\end{array}$ & \multirow{2}{*}{$\begin{array}{c}\text { Comments with respect } \\
\text { to the model } \\
\text { parameters }\end{array}$} \\
\hline & & $R M S E^{*}$ & $\Psi$ & $\Psi$ & \\
\hline 1. & Autoregressive models & 0.039 & 0.171 & 0.0340 & $\begin{array}{l}\text { AR Model }(1,2,6) \\
\text { R2 }=0.7340\end{array}$ \\
\hline 2. & $\begin{array}{l}\text { The crawling trend method- forecasting via } \\
\text { the harmonic balance method }\end{array}$ & 0.041 & 0.172 & 0.0615 & $\begin{array}{l}\text { Number of elements in } \\
\text { the segment } k=4\end{array}$ \\
\hline
\end{tabular}

The ex-ante error was set for 2015.

\section{Steel production and the proportions between production through the integrated and the electric process}

Steel, despite the development of competitive materials, is continuously classified as a basic construction material. The production of steel has dynamically increased in recent years. In 2004 it exceeded 1 billion tonnes (World Steel in Figures, 2005). 1.592 billion tonnes were produced across the world in 2015. However, due to the excess capacity there was a drop in production by ca. 2\% in 2015 compared to the previous year (World Steel in Figures, 2015). The global excess capacity amounted to 700 million tonnes (The Polish Steel Industry, 2016,

\footnotetext{
${ }^{1}$ The verification of methods was supervised by Prof. of the Silesian University of Technology Jan Szymszal PhD. Eng. (to whom the author expresses her sincere thanks).
} 
p. 18). The world markets are gradually experiencing a sluggish growth of the Chinese economy. The drop in the demand of steel was reported in steel-consuming sectors (construction, automotive industry, transport, domestic appliances). Over the long-term the situation on the world steel market shows an upward trend, with a slight drop in 2015. Since 1995 the average production growth rate has been positive. According to the data of the World Steel Association, the growth in the years 1995-2000 amounted to $2.5 \%$, in the consecutive years: 2001-2005 a growth of 6.2\% was recorded, in the next years the growth amounted to $4.5 \%$ and in the years 2010-2014 the increase was lower, ie. 3.8\% (World Steel in Figures, 2015).

In Europe production had a growing trend until 2008. The greatest amount of steel in Europe was produced in 2007-210 million tonnes. After the occurrence of the effects of the world economic crisis, the steel production trend in the EU countries showed fluctuations. In 2015 2\% less steel was produced in Europe than in the previous year (in 2014 steel production amounted to 168 million tonnes) (European Steel in Figures, 2007/2011; European Steel in Figures, 2008/2012).

In Poland since 2008 steel production has not exceeded 10 million tonnes. 9.2 million tonnes of steel were produced in Poland in 2015 (growth compared to the previous year by $8 \%$ ) at a production capacity of $73 \%$ (The Polish Steel Industry, 2016, p. 18). The highest production volume in the last decade was reported in 2007-10.7 million tonnes (Gajdzik, 2013).

Nowadays, steel is melted in converters (integrated process: blast furnace, converters, CSC - Continuous Steel Casting) and in electric furnaces (first of all arc furnaces). The state of technological development projected by experts for the set year 2050 will not change significantly, the mentioned technologies are considered to be essential (basic) in the metallurgical sector (Paduch, and Szulc, 2014, p. 3-11). In Poland there are two converter plants (converters of the type TBM - Thyssen Blast Metalurgie, LD - Linz-Donawitz), one in Cracow and one in Dąbrowa Unit of ArcelorMittal Poland. A technological process is a combination of converters with continuous steel casting. The other mills use electric furnaces. Among the advantages of this technology is the use of mainly collected (post amortization) steel scrap (the basic iron-bearing material) and steel scrap from post-production wastes of the mills for smelting of steel and a lower energy intensity as compared with the process of producing steel in integrated mills (in the blast furnace - oxygen converter system) (Łędzki, Zieliński, and Klimczyk, 2010, p. 7-14). The steel production technology in the electric furnaces is defined as EAF - Electric Arc Furnace and in converters as BOF - Basic Oxygen Furnace.

Until 2002 the mills in Poland also used open-hearth furnaces. However, the technology was discontinued for economic and environmental reasons. In Poland more steel is produced through the integrated process, rather than the electric process, although reverse situations occurred (such a situation occurred in the years 2009-2010 and was caused by the shut-down 
of redundant production capacities in integrated mills) (Gajdzik, 2013, p. 154-179). Currently (data from 2015) $58 \%$ of steel is produced through the converter process and $42 \%$ through the electric process (The Polish Steel Industry, 2016, p. 18). In the EU countries (27 countries) these proportions are slightly higher, as $61 \%$ constitutes converter steel and $39 \%$ of steel is melted in electric furnaces. The production of steel produced in Poland indicates a ca. 3\% lower share of steel produced through the converter process compared with the European Union and a ca. $17 \%$ lower share with regard to world production. Converter steel in the world constitutes over $75 \%$ of the total production (table 2) (Szulc, 2014).

Table 2.

Examples of shares of converter and electric steel in the overall steel production

\begin{tabular}{|c|c|c|c|c|c|c|c|c|c|c|c|c|}
\hline \multirow[t]{2}{*}{ Specification } & \multicolumn{4}{|c|}{ Poland [\%] } & \multicolumn{4}{|c|}{ EU [\%] } & \multicolumn{4}{|c|}{ The world [\%] } \\
\hline & 2005 & 2010 & 2012 & 2015 & 2005 & 2010 & 2012 & 2015 & 2005 & 2010 & 2012 & 2015 \\
\hline $\begin{array}{l}\text { The share of } \\
\text { converter steel }\end{array}$ & 58.7 & 49.9 & 50.5 & 58.0 & 61.1 & 58.7 & 58.4 & 61.0 & 65.3 & 65.2 & 70.5 & 75.0 \\
\hline $\begin{array}{l}\text { The share of } \\
\text { electric steel }\end{array}$ & 41.3 & 50.1 & 49.5 & 42.0 & 38.9 & 41.3 & 41.6 & 39.0 & 34.7 & 34.8 & 29.5 & 25.0 \\
\hline
\end{tabular}

Source: Compiled on the basis of data: World Steel in Figures, 2006, 2011, 2013, 2015, worldsteel Association; European Steel in Figures 2007/2011, 2008/2012 EUROFER; Polish Steel Industry, Metallurgical Chamber of Industry and Commerce, Katowice, 2006, 2011, 2013, 2016.

Apart from the overall converter and electric technology, steel production using openhearth furnaces is still indicated. The share of open-hearth processes in the total steel production in the world is insignificant (in 2015 it constituted barely $0.3 \%$ ) (World Steel in Figures, 2015). In the European Union the open-hearth technology is a historical technology (displayed in the statistical statements for the last time in 2010 at a level of 0.655 million tonnes) (World Steel in Figures, 2011).

\section{The time history analysis of the total steel production and according to the production processes in Poland}

On the basis of statistical data (table 3) the time history of the following examined volumes: overall steel production, steel production through the converter and electric processes was presented. The analyzed volumes were presented in the years 2000-2015.

Table 3.

Steel production in total and according to processes in the years 2000-2015

\begin{tabular}{|c|c|c|c|c|}
\hline NO. & Year & $\begin{array}{c}\text { Overall steel production } \\
\text { [million tonnes] }\end{array}$ & $\begin{array}{c}\text { Converter process } \\
\text { [million tonnes] }\end{array}$ & $\begin{array}{c}\text { Electric process } \\
\text { [million tonnes] }\end{array}$ \\
\hline 1 & 2000 & 10.498 & 6.800 & 3.285 \\
\hline 2 & 2001 & 8.809 & 5.823 & 2.809 \\
\hline 3 & 2002 & 8.367 & 5.799 & 2.561 \\
\hline 4 & 2003 & 9.107 & 6.070 & 3.037 \\
\hline
\end{tabular}




\begin{tabular}{|c|c|c|c|c|}
\hline 5 & 2004 & 10.578 & 6.858 & 3.721 \\
\hline 6 & 2005 & 8.336 & 4.893 & 3.443 \\
\hline 7 & 2006 & 9.992 & 5.766 & 4.225 \\
\hline 8 & 2007 & 10.631 & 6.198 & 4.433 \\
\hline 9 & 2008 & 9.727 & 5.225 & 3.502 \\
\hline 10 & 2009 & 7.128 & 3.236 & 3.998 \\
\hline 11 & 2010 & 7.993 & 3.995 & 4.353 \\
\hline 12 & 2011 & 8.776 & 4.424 & 4.132 \\
\hline 13 & 2012 & 8.348 & 4.227 & 3.551 \\
\hline 14 & 2013 & 7.950 & 4.399 & 3.491 \\
\hline 15 & 2014 & 8.558 & 5.067 & 5.323 \\
\hline 16 & 2015 & 9.202 & 5.39 & Comm \\
\hline
\end{tabular}

Source: Polish Steel Industry. Annual reports of the Metallurgical Chamber of Industry and Commerce in Katowice; access: www.hiph.org/polski_przemysl_handlowy.

In the years 2000-2002 steel in Poland was produced through the open hearth furnace (grey colour in table 3), yet its share was not significant (in the years 2000, 2001, 2002, steel production through the open hearth process in Poland amounted respectively to: $0.0413 \%$, $0.0177 \%$ and $0.0072 \%$ ).

The time history of the analyzed phenomena was presented in fig. 1. In general, the course of a series of examined phenomena is difficult because of the construction of a credible forecast - there are high random fluctuations (usually cyclical fluctuations). It is not possible to identify the seasonal (cyclical) fluctuations in the analyzed volumes. In case of the steel production volume a slightly declining trend is noticeable. The production of converter steel until 2009 showed a slightly declining trend and in the years 2009-2015 a growing trend. A reverse situation was reported in case of steel production in electric furnaces. A growing trend until 2009, a declining trend in two consecutive years and a growing trend once more. In fig. 1 situations were also highlighted when in the years 2009-2010 the production of converter steel had a smaller share in the overall steel production than electric steel.

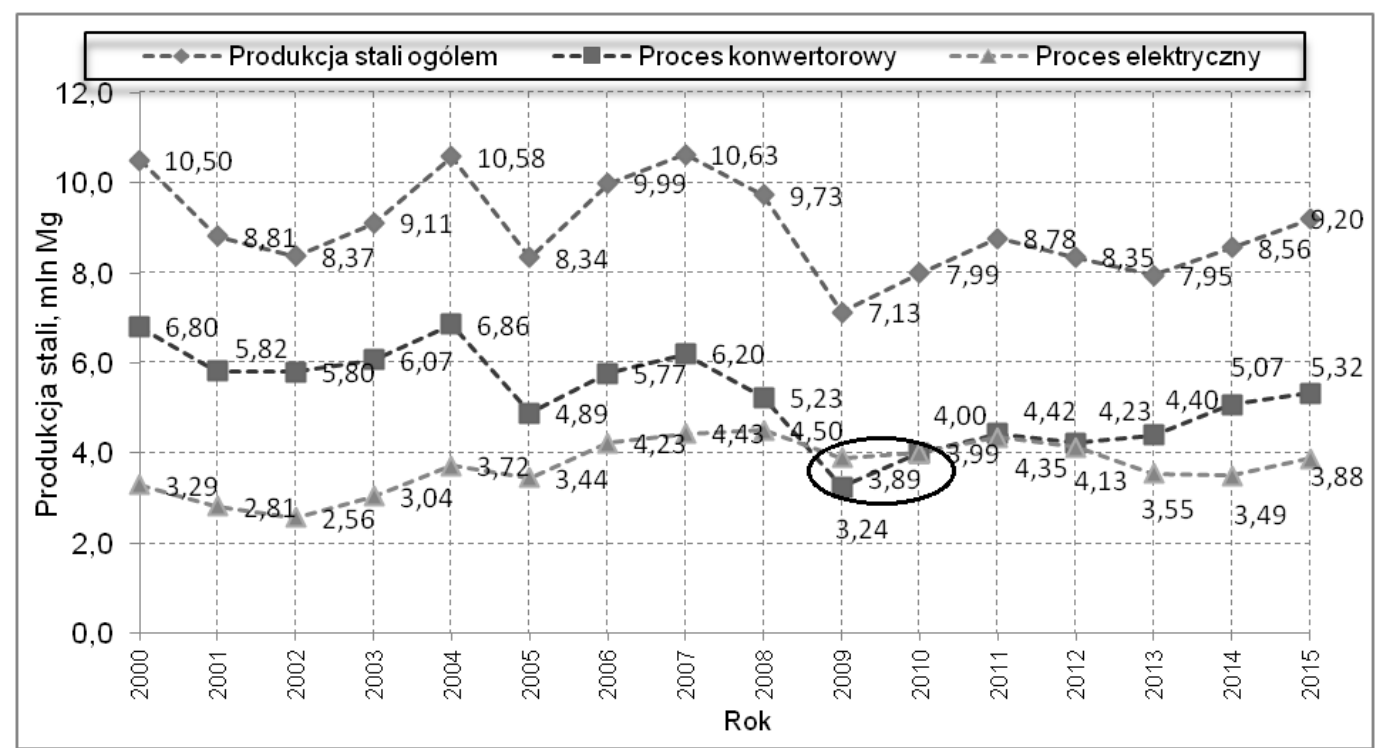

Figure 1. Steel production in total and according to production processes in the years 2000-2015. Source: own elaboration on the basis of statistical data (HIPH publications). 
Most steel is produced in the steel enterprise ArcelorMittal Poland. The enterprise produces about 5 million tonnes of steel annually. 5.2 million tonnes of steel was produced in the enterprise in 2015, what constitutes nearly 55\% of the overall steel production in Poland (Our steel, Your world, 2016, p. 26). The enterprise ArcelorMittal Poland produces steel through the converter process. More than $70 \%$ of steel produced in the steel enterprise is manufactured in the unit in Dąbrowa Górnicza (former Katowice Mill) and less than $30 \%$ in the unit in Cracow (former T. Sendzimir Mill) (table 4). The following mills use the electric furnace steelmaking technology: ArcelorMittal Warszawa S.A. (former Warsaw Mill) (15.7\% in the overall electric steel production); CMC Poland Sp. z o.o. (former Zawiercie Mill) (29.8\%); Celsa "Huta Ostrowiec" Sp. z o.o. (34.5\%); Ferrostal Łabędy Sp. z o.o. (Łabędy Mill) (10.9\%); Quality Steel Mill (5.8\%) and ISD Częstochowa Mill (0.6\%) (table 4).

Table 4.

The share of respective producers in the steel production using the converter and electric process

\begin{tabular}{|l|c|c|c|c|}
\hline Enterprise & year 2012 & year 2013 & year 2014 & $\begin{array}{c}\text { Share in the overall } \\
\text { production }\end{array}$ \\
\hline & {$[$ tonnes] } & {$[$ tonnes] } & {$[$ tonnes] } & 100 \\
\hline $\begin{array}{l}\text { Steel industry/steel production through } \\
\text { the converter process in total }\end{array}$ & 4226542 & 4399432 & 5066954 & 100 \\
\hline ArcelorMittal Poland & 4226542 & 4399432 & 5066954 & 73.4 \\
\hline $\begin{array}{l}\text { ArcelorMittal Poland Unit in Dąbrowa } \\
\text { Górnicza }\end{array}$ & 3028562 & 3057934 & 3719497 & 26.6 \\
\hline ArcelorMittal Poland Unit in Cracow & 1197980 & 1341498 & 1347457 & 100 \\
\hline $\begin{array}{l}\text { Steel industry/steel production through } \\
\text { the electric process in total }\end{array}$ & 4131618 & 3550904 & 3491464 & 15.7 \\
\hline ArcelorMittal Warszawa S.A. & 568322 & 554970 & 547870 & 34.5 \\
\hline Celsa "Huta Ostrowiec" Sp. z o.o. & 1196560 & 1023458 & 1204066 & 29.8 \\
\hline CMC Poland Sp. z o.o. & 1424047 & 1274089 & 1038817 & 10.9 \\
\hline Ferrostal Łabędy Sp. z o.o. & 303810 & 324645 & 381477 & 5.8 \\
\hline Quality Steel Mill & 159052 & 181049 & 200925 & 0.6 \\
\hline ISD Częstochowa Mill & 394440 & 95987 & 20746 & \\
\hline Source: HIPH. & & \\
\hline
\end{tabular}

Source: HIPH.

\section{Forecasting changes in the steel production volume in total and according to production processes - crawling trend model - forecasting via the harmonic balance method}

In the course of forecasting changes in the analyzed phenomenon, the crawling trend model was combined with the projection via the harmonic balance method.

\section{Assumptions:}

1. Segments were chosen after $\mathrm{k}=4$ observations.

2. Weights or coefficients taking account of the information obsolescence were calculated according to the formula: 


$$
C_{t+1}^{n}=\frac{1}{n-1} \cdot \sum_{i=1}^{t} \frac{1}{n-1} .
$$

Ex-ante projections were calculated according to the formula:

$$
y_{T}^{*}=y_{n}+(T-n) \cdot\left(\sum_{t=2}^{n} w_{t} \cdot c_{t}\right) \quad \text { dla } T=n+1, \ldots, \tau .
$$

The obtained modelling results were presented in the charts. As an example, the results of the overall steel production volume forecast until 2020 were provided in table 5.

\section{Table 5.}

\begin{tabular}{|c|c|c|c|c|c|c|c|c|c|c|c|c|c|c|c|c|c|c|c|c|c|c|c|c|c|}
\hline \multirow[b]{2}{*}{ LP } & \multicolumn{9}{|c|}{ Wartości modelowe $Y$ w poszczególnych segmentach $\quad k=4$} & \multirow{3}{*}{7} & \multirow{3}{*}{8} & \multirow{3}{*}{9} & \multirow{3}{*}{10} & \multirow{3}{*}{11} & \multirow{3}{*}{12} & \multirow{3}{*}{\begin{tabular}{|l|l}
13 & \\
&
\end{tabular}} & \multirow{3}{*}{\begin{tabular}{|c} 
Segm. \\
1
\end{tabular}} & & & \multirow{3}{*}{$\begin{array}{c}\text { Wt } \\
\text { przyrosty }\end{array}$} & & & \multirow{3}{*}{$\mathrm{Wt}^{*} \mathrm{Ct}$} & \multirow{3}{*}{$\frac{\left|y_{s}-y_{z}^{*}\right|}{y_{z}}$} & \multirow[b]{2}{*}{$\left(y_{1}-y_{i}^{\prime}\right)^{2}$} \\
\hline & Rok & $\begin{array}{c}\text { Produkcja stali } \\
\text { ogólem }\end{array}$ & $y^{* t}$ & 1 & 2 & 3 & 4 & 5 & 6 & & & & & & & & & $\begin{array}{r}\text { Esty } \\
\text { parametr } \\
\text { liniow } \\
\text { podol }\end{array}$ & $\begin{array}{l}\text { atory } \\
\text { w trendu } \\
\text { go dla } \\
\text { esów }\end{array}$ & & Ct-wagi ha & moniczne & & & \\
\hline 1 & 2000 & 10,498 & 9,888 & 9,9 & & & & & & & & & & & & & & $-0,46$ & \begin{tabular}{|l|}
932,8 \\
\end{tabular} & & Składniki & Wagi & & & \\
\hline 2 & 2001 & 8,809 & 8,867 & 9,4 & 8,3 & & & & & & & & & & & & 2 & 0,60 & $-1201,8$ & $-1,0204$ & 0,0044444 & 0,004444 & $-0,004534$ & 0,007 & 0,003 \\
\hline 3 & 2002 & 8,367 & 8,923 & 9,0 & 8,9 & 8,9 & & & & & & & & & & & 3 & 0,14 & $-266,7$ & 0,0556 & 0,0047619 & 0,009206 & 0,000512 & 0,066 & 0,309 \\
\hline 4 & 2003 & 9,107 & 9,123 & 8,5 & 9,5 & 9,0 & 9,4 & & & & & & & & & & 4 & 0,04 & $-72,7$ & 0,2000 & 0,0051282 & 0,014335 & 0,002866 & 0,002 & 0,338 \\
\hline 5 & 2004 & 10,578 & 9,596 & & 10,1 & 9,2 & 9,5 & 9,6 & & & & & & & & & 5 & 0,18 & $-353,6$ & 0,4731 & 0,0055556 & 0,019890 & 0,009410 & 0,093 & 0,565 \\
\hline 6 & 2005 & 8,336 & 9,393 & & & 9,3 & 9,5 & 9,8 & 8,9 & & & & & & & & 6 & 0,48 & $-956,1$ & $-0,2034$ & 0,0060606 & 0,025951 & $-0,005278$ & 0,127 & 1,117 \\
\hline 7 & 2006 & 9,992 & 9,941 & & & & 9,6 & 10,0 & 9,4 & 10,8 & & & & & & & 7 & $-0,95$ & 1915,1 & 0,5483 & 0,0066667 & 0,032617 & 0,017885 & 0,005 & 0,003 \\
\hline 8 & 2007 & 10,631 & 10,090 & & & & & 10,2 & 9,9 & 9,8 & 10,4 & & & & & & 8 & $-1,05$ & 2120,2 & 0,1488 & 0,0074074 & 0,040025 & 0,005955 & 0,051 & 0,293 \\
\hline 9 & 2008 & 9,727 & 9,347 & & & & & & 10,4 & 8,9 & 9,4 & 8,7 & & & & & 9 & $-0,20$ & 407,9 & $-0,7427$ & 0,0083333 & 0,048358 & $-0,035914$ & 0,039 & 0,145 \\
\hline 10 & 2009 & 7,128 & 8,048 & & & & & & & 7,9 & 8,3 & 8,5 & 7,4 & & & & 10 & 0,44 & $-885,1$ & $-1,2994$ & 0,0095238 & 0,057882 & $-0,075211$ & 0,129 & 0,845 \\
\hline 11 & 2010 & 7,993 & 7,947 & & & & & & & & 7,3 & 8,3 & 7,8 & 8,4 & & & 11 & $-0,06$ & 120,2 & $-0,1002$ & 0,0111111 & 0,068913 & $-0,006907$ & 0,006 & 0,002 \\
\hline 12 & 2011 & 8,776 & 8,313 & & & & & & & & & 8,1 & 8,3 & 8,3 & 8,6 & & 12 & $-0,11$ & 220,1 & 0,3657 & 0,0133333 & 0,082326 & 0,030107 & 0,053 & 0,215 \\
\hline 13 & 2012 & 8,348 & 8,367 & & & & & & & & & & 8,7 & 8,2 & 8,5 & 8,0 & 13 & 0,32 & $-629,9$ & 0,0536 & 0,0166667 & 0,098993 & 0,005309 & 0,002 & 0,000 \\
\hline 14 & 2013 & 7,950 & 8,299 & & & & & & & & & & & 8,2 & 8,4 & 8,4 & & & & $-0,0683$ & 0,02222222 & 0,121215 & $-0,008278$ & 0,044 & 0,121 \\
\hline 15 & 2014 & 8,558 & 8,462 & & & & & & & & & & & & 8,3 & 8,7 & & & & 0,1634 & 0,0333333 & 0,154549 & 0,025257 & 0,011 & 0,009 \\
\hline 16 & 2015 & 9,202 & 8,990 & & & & & & & & & & & & & 9,0 & & & & 0,5284 & 0,6666670 & 0,221215 & 0,116901 & 0,023 & 0,045 \\
\hline 17 & 2016 & & 9,280 & & & & & & & & & & & & & & & & & & & & 0,078080 & 0,044 & 0,521 \\
\hline 18 & 2017 & & 9,358 & & & & & & & & & & & & & & & & & & & & & $\psi$ & RMSE* $^{*}$ \\
\hline 19 & 2018 & & 9,437 & & & & & & & & & & & & & & & & & & & & & & \\
\hline 20 & 2019 & & 9,515 & & & & & & & & & & & & & & & & & & & & & & \\
\hline 21 & 2020 & & 9,593 & & & & & & & & & & & & & & & & & & & & & & \\
\hline
\end{tabular}

Projecting changes in the overall production volume [million tonnes]

The following steel production volumes were set on the basis of the crawling trend model with the projection via the harmonic balance method: 9.280 million tonnes in 2016; 9.358 million tonnes in 2017; 9.437 million tonnes in 2018; 9.515 million tonnes in 2019 and 9.593 million tonnes in 2020 . The projected steel volume indicates a slightly growing trend (fig. 2).

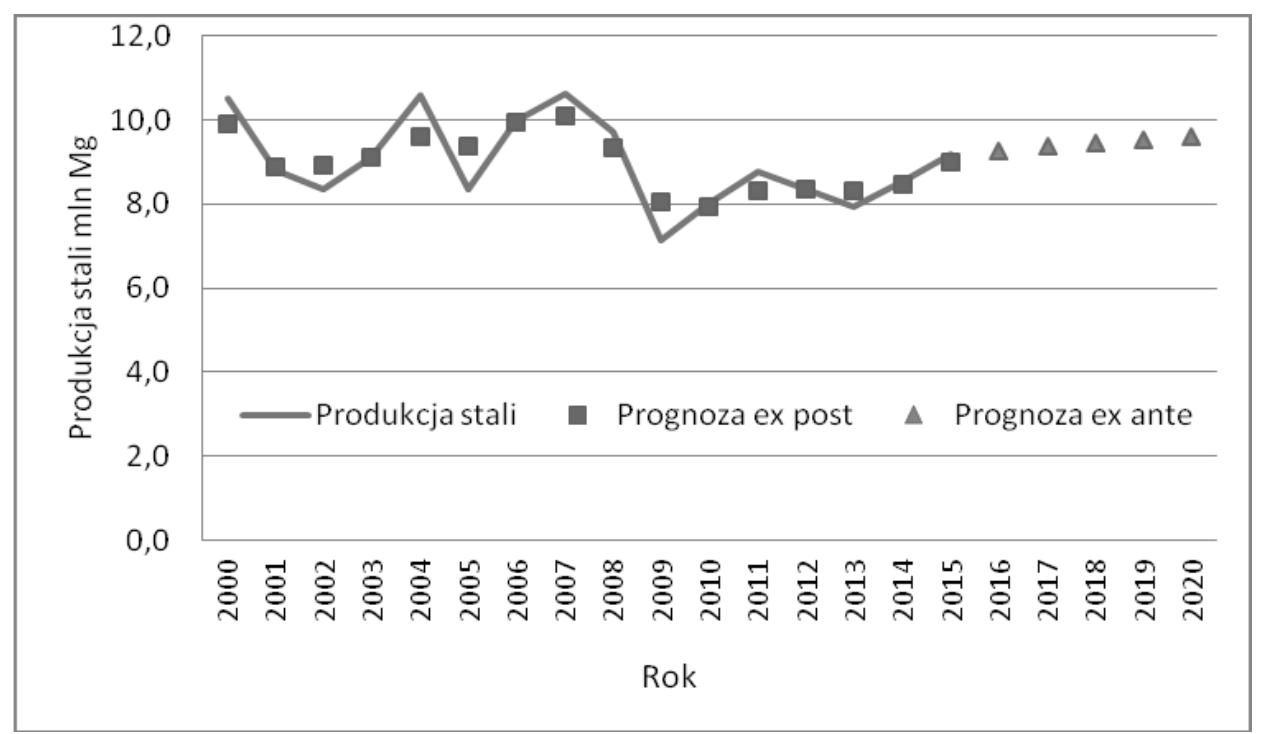

Figure 2. The projections of the overall steel production volume until 2020. Source: own elaboration on the basis of the research methodology presented in the publication. 
The following levels were obtained when projecting the steel production volume through the converter process: 5.433 million tonnes in 2016; 5.542 million tonnes in 2017, 5.652 million tonnes in 2018; 5.761 million tonnes in 2019; 5.871 million tonnes in 2020. Percentage shares of steel production through the converter process in the overall steel production were listed in table 6 . Figure 3 shows trends in the designated forecast - it is also a growing trend.

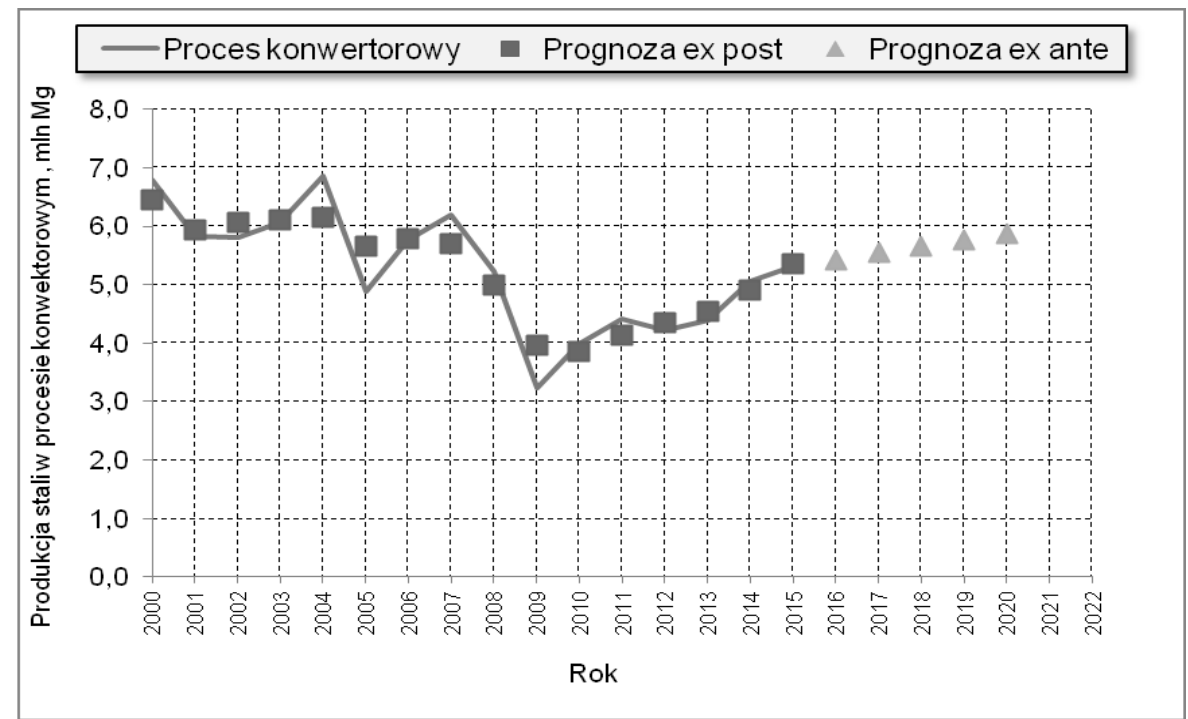

Figure 3. Projections of the steel production volume through the BOF converter process until 2020. Source: own elaboration on the basis of the research methodology presented in the publication.

Table 6.

Proportions between production in converter and electric furnaces

\begin{tabular}{|c|c|c|}
\hline Year & $\begin{array}{c}\text { Steel production through } \\
\text { the converter process [\%] }\end{array}$ & $\begin{array}{c}\text { Steel production through } \\
\text { the electric process [\%] }\end{array}$ \\
\hline 2000 & 64.7 & 31.3 \\
\hline 2001 & 66.1 & 31.9 \\
\hline 2002 & 69.3 & 30.7 \\
\hline 2003 & 66.6 & 33.4 \\
\hline 2004 & 64.8 & 35.2 \\
\hline 2005 & 58.7 & 41.3 \\
\hline 2006 & 57.7 & 42.3 \\
\hline 2007 & 58.3 & 41.7 \\
\hline 2008 & 53.7 & 46.3 \\
\hline 2009 & 45.4 & 54.6 \\
\hline 2010 & 49.9 & 50.1 \\
\hline 2011 & 50.4 & 49.6 \\
\hline 2012 & 50.6 & 49.4 \\
\hline 2013 & 55.3 & 44.7 \\
\hline 2014 & 59.2 & 40.8 \\
\hline 2016 & 57.8 & 42.2 \\
\hline 2017 & 58.5 & 41.5 \\
\hline 2018 & 59.2 & 40.8 \\
\hline 2019 & 59.9 & 40.1 \\
\hline & 60.5 & 39.5 \\
\hline & 61.2 & 38.8 \\
\hline
\end{tabular}


The projections of the steel production volume through the electric process are the following: 3.850 million tonnes in 2016; 3.820 million tonnes in 2017, 3.790 million tonnes in 2018; 3.761 million tonnes in 2019; 3.731 million tonnes in 2020. Percentage shares of steel production through the electric process in the overall steel production were listed in table 6 . Figure 4 shows trends in the designated forecast - It is a slightly declining trend. A slight drop in the production of steel in electric furnaces may be caused by the reduction in the production capacity of the mills. The Polish steel market has already suffered sharp declines in steel production through the electric processes, eg. in 2012 ISD Częstochowa Mill produced 394440 tonnes of steel and two years later 20746 tonnes (drop by 95\%).

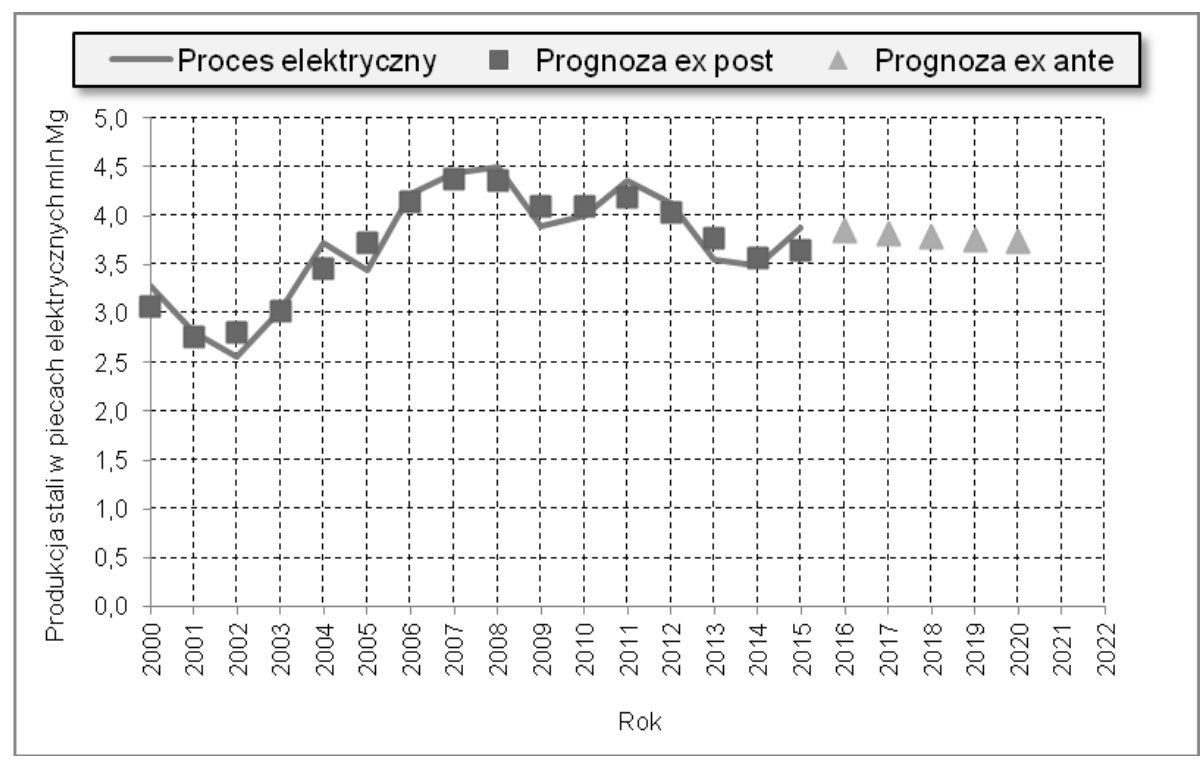

Figure 4. Projections of the steel production volume through the electric (EAF) process until 2020. Source: own elaboration on the basis of the research methodology presented in the publication.

The obtained results of all forecasts - crawling trend model with the projection via the harmonic balance method were listed in table 7 .

\section{Table 7.}

Summary of the obtained forecasts of the steel production volume in total and according to technological processes

\begin{tabular}{|c|c|c|c|}
\hline Year & $\begin{array}{c}\text { Projected steel production } \\
\text { volume in total } \\
\text { [million tonnes] }\end{array}$ & $\begin{array}{c}\text { Projected steel production } \\
\text { volume through the converter } \\
\text { process } \\
\text { [million tonnes] }\end{array}$ & $\begin{array}{c}\text { Projected steel production } \\
\text { volume through the electric } \\
\text { process } \\
\text { [million tonnes] }\end{array}$ \\
\hline 2016 & 9.280 & 5.433 & 3.850 \\
\hline 2017 & 9.358 & 5.542 & 3.820 \\
\hline 2018 & 9.437 & 5.652 & 3.790 \\
\hline 2019 & 9.515 & 5.761 & 3.761 \\
\hline 2020 & 9.593 & 5.871 & 3.731 \\
\hline
\end{tabular}

Source: own elaboration on the basis of the research methodology presented in the publication. 


\section{The projected steel production volume according to processes in available studies}

The steel production volume forecast was carried out by the Polish Electricity Association (PKEE) (Report 2030, 2008) ${ }^{2}$. On the basis of the worked out scenarios, the steel production does not exceed the current production capacity and the proportions between production in electric furnaces (EAF) and converter furnaces are slightly changing in favour of production in electric furnaces (table 8). The forecasts were carried out in 2007, assuming empirical evidence based on the production of steel in the years 1996-2006 (table 8). The forecasts of the steel production volume and the proportion between production in electric and converter furnaces were determined until 2030. Two scenarios were developed on the basis of data: the baseline and the moderate scenario (table 8 ).

Table 8.

Forecasts of the steel production volume and the proportion between production in converter and electric (arc) furnaces

\begin{tabular}{|c|c|c|c|c|c|c|c|c|c|c|}
\hline \multirow[b]{2}{*}{ Year } & \multicolumn{2}{|c|}{ Statistics } & \multicolumn{4}{|c|}{ Baseline } & \multicolumn{4}{|c|}{ Moderate } \\
\hline & $\begin{array}{c}\text { BOF } \\
\text { Steel } \\
\text { [million } \\
\text { tonnes] }\end{array}$ & $\begin{array}{c}\text { EAF } \\
\text { Steel } \\
\text { [million } \\
\text { tonnes] }\end{array}$ & $\begin{array}{c}\text { BOF } \\
\text { Steel } \\
\text { [million } \\
\text { tonnes] }\end{array}$ & $\begin{array}{c}\text { BOF } \\
\text { Steel } \\
{[\%]}\end{array}$ & $\begin{array}{c}\text { EAF } \\
\text { Steel } \\
\text { [million } \\
\text { tonnes] }\end{array}$ & $\begin{array}{c}\text { EAF } \\
\text { Steel } \\
{[\%]}\end{array}$ & $\begin{array}{c}\text { BOF } \\
\text { Steel } \\
\text { [million } \\
\text { tonnes] }\end{array}$ & $\begin{array}{l}\text { BOF } \\
\text { Steel } \\
{[\%]}\end{array}$ & $\begin{array}{c}\text { EAF } \\
\text { Steel } \\
\text { [million } \\
\text { tonnes] }\end{array}$ & $\begin{array}{c}\text { EAF } \\
\text { Steel } \\
{[\%]}\end{array}$ \\
\hline 1996 & 6.757 & 2.554 & & & & & & & & \\
\hline 1997 & 7.531 & 2.994 & & & & & & & & \\
\hline 1998 & 6.223 & 3.143 & & & & & & & & \\
\hline 1999 & 5.452 & 3.022 & & & & & & & & \\
\hline 2000 & 6.794 & 3.290 & & & & & & & & \\
\hline 2001 & 5.823 & 2.809 & & & & & & & & \\
\hline 2002 & 5.799 & 2.561 & & & & & & & & \\
\hline 2003 & 6.070 & 3.037 & & & & & & & & \\
\hline 2004 & 6.858 & 3.721 & & & & & & & & \\
\hline 2005 & 5.001 & 3.443 & & & & & & & & \\
\hline 2006 & 5.766 & 4.242 & & & & & & & & \\
\hline 2010 & \multicolumn{2}{|c|}{ Forecasts } & 7.000 & 58.3 & 5.000 & 41.7 & 6.200 & 59.6 & 4.200 & 40.4 \\
\hline 2015 & \multicolumn{2}{|c|}{ Forecasts } & 7.200 & 55.4 & 5.800 & 44.6 & 6.300 & 59.4 & 4.300 & 40.6 \\
\hline 2020 & \multicolumn{2}{|c|}{ Forecasts } & 7.400 & 53.6 & 6.400 & 46.4 & 6.400 & 57.2 & 4.800 & 42.8 \\
\hline 2025 & \multirow{2}{*}{\multicolumn{2}{|c|}{$\begin{array}{l}\text { Forecasts } \\
\text { Forecasts }\end{array}$}} & 7.400 & 52.1 & 6.800 & 47.9 & 6.500 & 56.5 & 5.000 & 43.5 \\
\hline 2030 & & & 7.400 & 51.4 & 7.000 & 48.6 & 6.600 & 56.9 & 5.000 & 43.1 \\
\hline
\end{tabular}

Report 2030: The impact of the proposed EU regulations in terms of implementing the European development strategy of $\mathrm{CO} 2$-free energy production on Poland's energy safety and, in particular, the options to restore generation capacities using fossil fuels and the prices of electricity. App. 2. Assumptions concerning the levels of activity and energy intensity of distinguished types of production or services, Warsaw, June 2008. The study was carried out by the company Badania Systemowe EnergoSys on behalf of PKEE, access: www.toe.pl/plwybrane-dokumenty/rok2008? download=455:załącznik-2.

Because the forecast was evaluated in 2007, it is possible to refer the projected volumes from the years 2010 and 2015 to the actual production (table 9). This summary will enable to

\footnotetext{
${ }^{2}$ The study was carried out by the company Badania Systemowe EnergoSys on behalf of PKEE. Retrieved from www.toe.pl/plwybrane-dokumenty/rok-2008?download=455:załącznik-2.
} 
determine the differences between the projected and actual volumes. The obtained (positive) differences are evidence of overestimated volumes of the forecast in the considered scenarios. In case of the baseline scenario, the dynamics of changes is greater than in the moderate scenario. Assuming that the indicators of the dynamics of changes are forecast errors, the volumes in forecasts for 2020 and the next years were verified (table 10). The dynamics of changes was calculated according to the following formula:

$$
D z=\frac{P Z-W r}{P Z} \times 100 \%
$$

where:

$\mathrm{Dz}$ - indicator of the dynamics of changes,

$\mathrm{Pz}$ - projected volumes of the analyzed phenomenon,

$\mathrm{Wr}$ - actual volume.

Table 9.

Differences between the projected and actual volumes in the overall steel production volume and in the technological processes

\begin{tabular}{|c|c|c|c|c|c|}
\hline No. & Specification & 2010 & $\begin{array}{l}\text { Indicator } \\
\text { of the } \\
\text { dynamics } \\
\text { of } \\
\text { changes }\end{array}$ & 2015 & $\begin{array}{l}\text { Indicator } \\
\text { of the } \\
\text { dynamics } \\
\text { of } \\
\text { changes }\end{array}$ \\
\hline 1 & $\begin{array}{l}\text { Baseline - forecast of the volume of produced steel in } \\
\text { total [million tonnes] (projected volume of the analyzed } \\
\text { phenomenon) }\end{array}$ & 12.000 & - & 13.000 & - \\
\hline 2 & $\begin{array}{l}\text { Actual volumes of produced steel [million tonnes] } \\
\text { (actual volume) }\end{array}$ & 7.993 & - & 9.202 & - \\
\hline \multicolumn{2}{|r|}{$\begin{array}{l}\text { Difference between the projected and actual volumes [million } \\
\text { tonnes] }(1-2)\end{array}$} & 4.007 & $33.39 \%$ & 3.798 & $29.21 \%$ \\
\hline 3 & $\begin{array}{l}\text { Baseline - forecast of the volume of produced steel in } \\
\text { the BOF technology [million tonnes] (projected volume } \\
\text { of the analyzed phenomenon) }\end{array}$ & 7.000 & - & 7.200 & - \\
\hline 4 & $\begin{array}{l}\text { Actual volumes of produced steel in the BOF technology } \\
\text { [million tonnes] (actual volume) }\end{array}$ & 3.995 & - & 5.323 & - \\
\hline \multicolumn{2}{|r|}{$\begin{array}{l}\text { Difference between the projected and actual volumes [million } \\
\text { tonnes] }(3-4)\end{array}$} & 3.005 & $42.92 \%$ & 1.877 & $26.06 \%$ \\
\hline 5 & $\begin{array}{l}\text { Baseline - forecast of the volume of produced steel in } \\
\text { the EAF technology [million tonnes] (projected volume } \\
\text { of the analyzed phenomenon) }\end{array}$ & 5.000 & - & 5.800 & - \\
\hline 6 & $\begin{array}{l}\text { Actual volumes of produced steel in the EAF technology } \\
\text { [million tonnes] (actual volume) }\end{array}$ & 3.998 & - & 3.879 & - \\
\hline \multicolumn{2}{|r|}{$\begin{array}{l}\text { Difference between the projected and actual volumes [million } \\
\text { tonnes] }(5-6)\end{array}$} & 1.002 & $20.04 \%$ & 1.921 & $33.12 \%$ \\
\hline 7 & $\begin{array}{l}\text { Moderate scenario - forecast of the volume of the } \\
\text { produced steel in total [million tonnes] (projected } \\
\text { volume of the analyzed phenomenon) }\end{array}$ & 10.400 & - & 10.600 & - \\
\hline 8 & $\begin{array}{l}\text { Actual volumes of produced steel [million tonnes] } \\
\text { (actual volume) }\end{array}$ & 7.993 & - & 9.202 & - \\
\hline \multicolumn{2}{|r|}{$\begin{array}{l}\text { Difference between the projected and actual volumes [million } \\
\text { tonnes] }(7-8)\end{array}$} & 2.407 & $23.14 \%$ & 1.398 & $13.19 \%$ \\
\hline 9 & $\begin{array}{l}\text { Moderate scenario - forecast of the volume of produced } \\
\text { steel in the BOF technology [million tonnes] (projected } \\
\text { volume of the analyzed phenomenon) }\end{array}$ & 6.200 & - & 6.300 & - \\
\hline
\end{tabular}




\begin{tabular}{|c|l|c|c|c|c|}
\hline 10 & $\begin{array}{l}\text { Actual volume of produced steel in the BOF technology } \\
\text { [million tonnes] (actual volume) }\end{array}$ & 3.995 & - & 5.323 & - \\
\hline $\begin{array}{l}\text { Difference between projected and actual volumes [million } \\
\text { tonnes] (9-10) }\end{array}$ & 2.205 & $35.56 \%$ & 0.977 & $15.50 \%$ \\
\hline 11 & $\begin{array}{l}\text { Moderate scenario - forecast of the volume of produced } \\
\text { steel in the EAF technology [million tonnes] (projected } \\
\text { value of the analyzed phenomenon) }\end{array}$ & 4.200 & - & 4.300 & - \\
\hline 12 & $\begin{array}{l}\text { Actual volumes of produced steel in the EAF technology } \\
\text { [million tonnes] (real value) }\end{array}$ & 3.998 & - & 3.879 & - \\
\hline $\begin{array}{l}\text { Difference between the projected and actual volumes [million } \\
\text { tonnes] (11-12) }\end{array}$ & 0.202 & $4.8 \%$ & 0.421 & $9.79 \%$ \\
\hline
\end{tabular}

Source: Projections from: Report 2030: The impact of the proposed EU regulations in terms of implementing the European development strategy of CO2-free energy production on Poland's energy safety and, in particular, the options to restore generation capacities using fossil fuels and the prices of electricity. App. 2. Statistical data concerning the volume of steel production from the reports: Polish Steel Industry, Metallurgical Chamber of Industry and Commerce (HIPH), Katowice.

Table 10.

Verified projections of the value of steel production in total and according to production technology

\begin{tabular}{|c|c|c|c|c|c|c|c|c|}
\hline \multirow[t]{2}{*}{ No. } & \multirow[b]{2}{*}{ 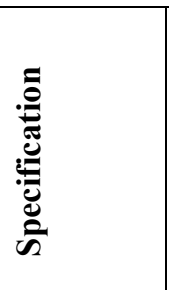 } & \multirow[b]{2}{*}{ 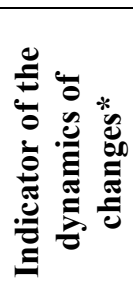 } & \multicolumn{2}{|c|}{2020} & \multicolumn{2}{|c|}{2025} & \multicolumn{2}{|c|}{2030} \\
\hline & & & 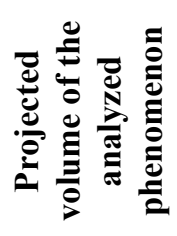 & 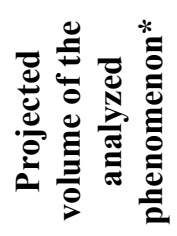 & 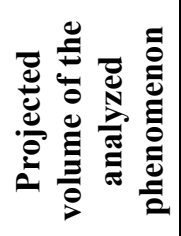 & 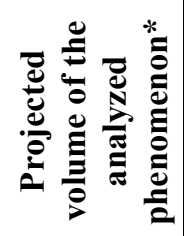 & 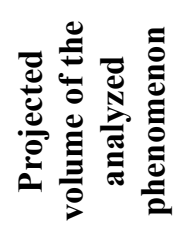 & 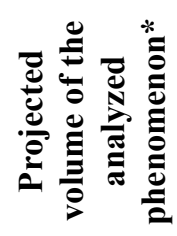 \\
\hline \multirow[t]{2}{*}{1} & \multirow{2}{*}{ 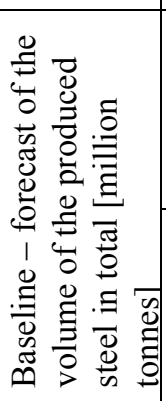 } & $33.39 \%$ & \multirow[b]{2}{*}{13.800} & 9.192 & \multirow[b]{2}{*}{14.200} & 9.459 & \multirow[b]{2}{*}{14.400} & 9.592 \\
\hline & & $29.21 \%$ & & 9.769 & & 10.052 & & 10.194 \\
\hline \multirow[t]{2}{*}{2} & \multirow{2}{*}{ 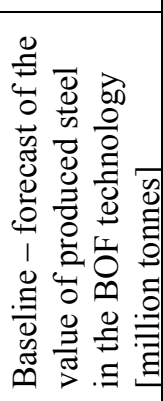 } & $42.92 \%$ & \multirow[b]{2}{*}{7.400} & 4.224 & \multirow[b]{2}{*}{7.400} & 4.224 & \multirow[b]{2}{*}{7.400} & 4.224 \\
\hline & & $26.06 \%$ & & 5.471 & & 5.471 & & 5.471 \\
\hline \multirow[t]{2}{*}{3} & \multirow{2}{*}{ 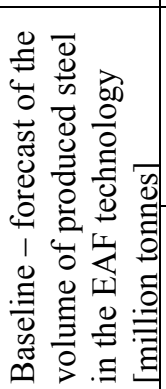 } & $20.04 \%$ & \multirow[b]{2}{*}{6.400} & 5.117 & \multirow[b]{2}{*}{6.800} & 5.437 & \multirow[b]{2}{*}{7.000} & 5.5972 \\
\hline & & $33.12 \%$ & & 4.280 & & 4.548 & & \\
\hline
\end{tabular}




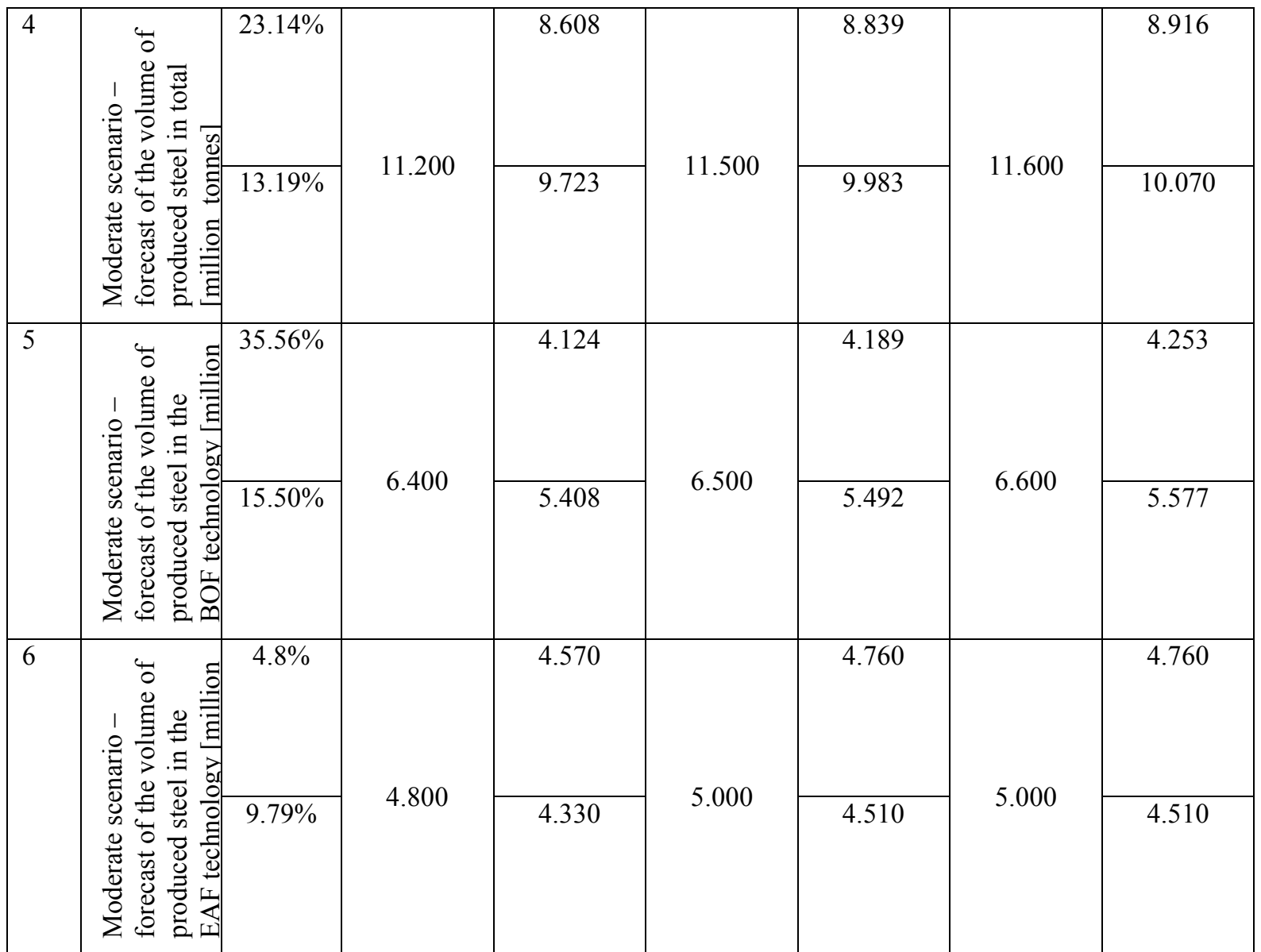

* dynamics indicators from table 9 for the years 2010, 2015, Projected volume of the analyzed phenomenon*adjusted forecast.

Source: own study.

Adjusted forecasts of PKEE (Polish Electricity Association) were referred to forecasts of the overall steel production volume and broken down by respective technological processes carried out on the basis of the crawling trend model with the projection via the harmonic balance method. The obtained results were presented in table 11 .

\section{Table 11.}

Summary of the projected changes in the volume of steel production in total and according to technological processes in 2020

\begin{tabular}{|l|c|c|c|}
\hline Specification & $\begin{array}{c}\text { Crawling trend } \\
\text { model }\end{array}$ & $\begin{array}{c}\text { Baseline of PKEE } \\
\text { (Polish Electricity } \\
\text { Association) }\end{array}$ & $\begin{array}{c}\text { Moderate } \\
\text { scenario of PKEE } \\
\text { (Polish Electricity } \\
\text { Association) }\end{array}$ \\
\hline $\begin{array}{l}\text { Forecast of the volume of produced steel } \\
\text { in total [million tonnes] }\end{array}$ & 9.593 & $9.192-9.769$ & $8.608-9.723$ \\
\hline $\begin{array}{l}\text { Forecast of the volume of produced steel } \\
\text { in the BOF technology [million tonnes] }\end{array}$ & 5.871 & $4.224-5.471$ & $4.24-5.408$ \\
\hline $\begin{array}{l}\text { Forecast of the volume of produced steel } \\
\text { in the EAF technology [million tonnes] }\end{array}$ & 3.731 & $4.280-5.117$ & $4.330-4.570$ \\
\hline
\end{tabular}

Source: own study. 


\section{Conclusions}

On the basis of the summary (table 11), it can be concluded that the respective forecasts of the volume of steel produced in Poland will not exceed 10 million tonnes in 2020. According to the optimistic scenario metallurgical enterprises will produce ca. 9.7 million tonnes and according to the moderate scenario from 9.2 to 9.5 million tonnes. The pessimistic scenario assumes the production at the level of 8.6 million tonnes. The share of steel obtained through the BOF technology in the total steel production can assume two extreme scenarios: the share of this technology will still be significant (reaching even $60 \%$ of production in total) or it will drop and the share of steel obtained from electric furnaces will slightly increase. According to the second scenario, the shares of respective technologies in the total steel production will slightly differ from the current ones (table 6). It can be concluded that in 2020 in the range of the steel production technology in Poland there will not be any major changes (the present proportions shall be maintained). In the long run (projections until 2050) the increase of the share of recovered scrap from the present $45 \%$ to $70 \%$ will entail the increase of the share of the electric process in the production of steel (Paduch, and Szulc, 2014, p. 3-11). When the present proportions are reversed, the approximate $60 \%$ of steel shall not be produced through the converter process, but in electric furnaces. Reaching the proportion: $40 \%$ - integrated process and $60 \%$ - electric furnaces is dictated by ecological requirements - reduction of $\mathrm{CO}_{2}$ emissions (the adopted proportions will reduce the $\mathrm{CO}_{2}$ emissions from the present level of 1.8 to 0.6 tonnes per 1 tonne of steel in 2050) (Paduch, and Szulc, 2014, p. 3-11). The technological changes will also bring about energy savings - lower energy consumption from the current level of $21 \mathrm{GJ}$ to $8.6 \mathrm{GJ}$ per tonne of steel. Within the next three years (shortterm forecast until 2020) the Polish steel sector will not record any major changes. The current production capacity amounts to 13.055 million tonnes of crude steel, including 7.6 million tonnes in the integrated process.

\section{Bibliography}

1. European Steel in Figures 2007/2011. EUROFER.

2. European Steel in Figures 2008/2012. EUROFER.

3. Gajdzik, B. (2013). Restrukturyzacja przedsiębiorstw hutniczych $w$ zestawieniach statystycznych i badaniach empirycznych. Gliwice: Wydawnictwo Politechniki Śląskiej.

4. Łędzki, A., Zieliński, K., Klimczyk, A. (2010). Podstawy technologii wytwarzania $i$ przetwarzania. Część V Stalownictwo (materiaty wewnętrzne). Kraków: Akademia Górniczo-Hutnicza, Wydział Inżynierii Metali i Informatyki Przemysłowej. 
5. Nasza stal, Twój świat (2016). Raport Zrównoważonego Rozwoju. Dąbrowa Górnicza: ArcelorMittal Poland.

6. Paduch, J., and Szulc W. (2014). Renesans przemysłu stalowego w Unii Europejskiej. Prace Instytut Metalurgii Żelaza, $n r$ 3, s. 3-11.

7. Pawłowski, Z. (1973). Prognozy ekonometryczne. Warszawa: PWN.

8. Pawłowski, Z. (1982). Zasady predykcji ekonometrycznej. Warszawa: PWN.

9. Polski przemyst stalowy. Roczne raporty Hutniczej Izby Przemysłowo-Handlowej w Katowicach. Retrieved from www.hiph.org/polski_przemysl_handlowy.

10. Raport 2030: Wptyw proponowanych regulacji unijnych $w$ zakresie wprowadzenia europejskiej strategii rozwoju energetyki wolnej od emisji $\mathrm{CO}_{2}$ na bezpieczeństwo energetyczne Polski, a w szczególności możliwości odbudowy mocy wytwórczych wykorzystujacych paliwa kopalniane oraz poziom cen energii elektrycznej. Zat. 2. Założenia dotyczace poziomów aktywności i energochłonności wyróżnionych rodzajów produkcji lub ustug (2008). Warszawa: Badania Systemowe EnergoSys na zlecenie PKEE. Retrieved from www.toe.pl/plwybrane-dokumenty/rok-2008?download=455: załącznik-2.

11. Sadowski, W. (1997). Ekonometria. Warszawa: Wydawnictwo Prywatnej Wyższej Szkoły Handlowej.

12. Szulc, W. (2014). Transformacja polskiego hutnictwa żelaza do gospodarki wolnorynkowej (z uzupełnieniami). Prace Instytutu Metalurgii Żelaza, $n r 6$.

13. World Steel in Figures 2005. World Steel Association (worldsteel). Retrieved from worldsteel.org.

14. World Steel in Figures 2011. World Steel Association (worldsteel). Retrieved from worldsteel.org.

15. World Steel in Figures 2013. World Steel Association (worldsteel). Retrieved from worldsteel.org.

16. World Steel in Figures 2014. World Steel Association (worldsteel). Retrieved from worldsteel.org.

17. World Steel in Figures 2015. World Steel Association (worldsteel). Retrieved from worldsteel.org. 